\title{
Molecular and Phenotypic Characterization for Leaf Rust Resistance in Bread Wheat (Triticum aestivum L.)
}

\author{
Arati Yadawad", R.R. Hanchinal, H.L. Nadaf, S.A. Desai, \\ Suma Biradar and V. Rudranaik
}

Department of Genetics and Plant Breeding, University of Agricultural Sciences, Dharwad-58000, Karnataka, India

*Corresponding author

\section{A B S T R A C T}

\section{Keywords}

Marker assisted selection, Leaf rust, Resistance genes, Triticum aestivum

Article Info

Accepted:

12 September 2018 Available Online: 10 October 2018
Present study aimed at molecular and phenotypic characterization of $F_{3}$ population of a cross between leaf rust susceptible but well adapted bread wheat variety DWR 162 and resistant variety PBW 343 carrying highly effective alien genes $L r 24$ and $L r 28$ to identify recombinant lines with high productivity and leaf rust resistance. Fifty nine $\mathrm{F}_{3}$ lines with seven checks were evaluated for yield and yield contributing traits in randomized block design (RBD) with two replications. These lines were also screened against most virulent pathotypes of leaf rust 77-5 (121R63-1) in rust screening nursery. SCAR markers, namely SCS1302 207 and SCS42 $1_{570}$ linked to $\operatorname{Lr} 24$ and $\operatorname{Lr} 28$ genes facilitated identification of individual lines possessing the targeted genes. To identify the lines that mostly resemble 'DWR 162' variety, DUS (Distinctiveness Uniformity Stability) characterization was done. Nine lines were identified in $\mathrm{F}_{3}$ generation, possessing high yield potential and leaf rust resistance genes, $\operatorname{Lr} 24$ and $\operatorname{Lr} 28$ with the desirable features of DWR 162. Availability of a combination of two major rust resistance genes would facilitate the breeding program for developing new leaf rust resistant and high yielding cultivars.

\section{Introduction}

Bread wheat (Triticum aestivum L.) is one of the most important cereal crops worldwide (second after maize), providing staple food for $35 \%$ of the world population. Leaf rust caused by the fungus Puccinia triticina Eriks. is one of the most common foliar diseases of wheat worldwide (Oelke and Kolmer, 2004; Mebrate et al., 2008). Severe leaf rust epidemics can cause yield losses up to $40 \%$ (Knott, 1989). Use of resistant wheat cultivars is the most economic and environmentally safe way to reduce losses caused by leaf rust. Till date 71 genes for resistance to leaf rust have been cataloged in wheat (Singh et al., 2012). Most $L r$ genes confer race-specific seedling resistance and are vulnerable to defeat by new virulent races. Greater durability of resistance could be achieved through combinations of race-specific genes (Kolmer et al., 2008a, 2008b).

MAS has allowed concurrent introgression of more than one targeted gene into otherwise elite crop varieties, and thus has been found to 
improve significantly the efficiency and effectiveness of conventional breeding (Gupta et al., 2010).

Available molecular markers, tightly linked to desired $L r$ genes help in the selection of individuals with introduced genes, within segregating populations. In wheat, gene pyramiding using MAS has been achieved for resistance against leaf rust (Cox et al., 1994; Gupta et al., 2005; Singh et al., 2004; Nocente et al., 2007; Revati et al., 2010 and Chhuneja et al., 2011).

Present study aimed at molecular and phenotypic characterization of $\mathrm{F}_{3}$ population from a cross between the leaf rust resistant parent PBW 343 carrying Lr24 and Lr28 and a susceptible parent DWR 162 to identify recombinant lines resembling DWR 162 with high productivity and leaf rust resistant genes Lr24 and Lr28.

\section{Materials and Methods}

The bread wheat genotype DWR 162, which is susceptible to leaf rust evolved by pedigree method from a cross between Kavakaz/Buho// Kalyanasona/Bobwhite, was selected as female parent. 'PBW 343' a ruling variety of North Western Plains Zone with two effective leaf rust resistance genes, $L r 24$ and $L r 28$ was used as a male parent.

The desired crosses were made in the polyhouse and in fields of Dr. Sanjay Rajaram Wheat Laboratory, All India Coordinated Wheat Improvement Project (AICWIP), Main Agricultural Research Station (MARS), University of Agricultural Sciences, Dharwad and alternate generations were grown in off season at Indian Agricultural Research Institute, Regional Research Station, Wellington, Tamil Nadu. The recommended package of practices was followed for raising the crop.
$F_{1}$ seeds of the cross DWR 162 X PBW 343 were sown in spaced planting and individual plants of $\mathrm{F}_{1}$ 's of the cross DWR $162 \mathrm{X}$ PBW 343 were confirmed for the presence of $L r 24$ and $L r 28$ genes using SCAR markers linked to leaf rust resistance genes $L r 24$ and $L r 28$. Individual plants negative for donor gene under transfer were removed. Individual $\mathrm{F}_{1}$ plants with $L r 24$ and $L r 28$ were selfed to get $F_{2}$ population and 121 individual $F_{2}$ plants were grown in the field in space planting. These plants were confirmed for the presence of $L r 24$ and $L r 28$ and the $\mathrm{F}_{2}$ plants which carry both $L r 24$ and $L r 28$ were selfed to get $\mathrm{F}_{3}$ population for evaluation and selection of superior recombinant lines.

A total of $59 \mathrm{~F}_{3}$ lines along with two parents, DWR 162, PBW 343 and five checks viz., UAS 304, HI 977, GW 322, UAS 304 and HS 240 were sown in two replications. Observations were recorded on DUS characters and also Morpho-physiological characters on five randomly selected plants in each progeny row line of two replications.

\section{Disease screening}

One of the replication of the $\mathrm{F}_{3}$ segregating progeny was sown at rust screening nursery for screening of leaf rust resistance at the seedling stage with leaf rust pathotype 77-5, virulent on recurrent parent 'DWR 162'. On the appearance of symptoms, rust severity (percentage) and response of the plants to disease were assessed using a modified Cobb's scale (Peterson et al., 1948).

The final disease severity data for the leaf rust was converted into an Average Coefficient of Infection (ACI) by multiplying severity with a constant value for field response (Stubbs et al., 1986 and Roelf et al., 1992). Leaf rust screening along with molecular marker analysis was used to follow the genes during these selfing generations. 
DNA isolation, PCR conditions and electrophoresis

Based on DUS characters and Morphophysiological characters recorded for 59 lines of $F_{3}$ in two replications, only superior lines with high productivity and DWR 162 type characters were selected and 10 plants per line were selected randomly and confirmed for the presence of $L r 24$ and $L r 28$ genes.

DNA isolation of parental genotypes and backcross progenies was carried out from onemonth-old plants using a CTAB method (Dellaporta et al., 1983). The PCR amplification was carried out in a reaction mixture of $20 \mu \mathrm{l}$ containing 200M dNTPs (MBI; Fermentas, Lithuania, USA), $0.75 \mathrm{U}$ Taq DNA polymerase (MBI; Fermentas, Lithuania, USA), 5 pmole of each primer, 20 30 ng template DNA and $10 X$ PCR buffer (10 $\mathrm{mM}$ Tris, $\mathrm{pH} 8.4,50 \mathrm{mM} \mathrm{KCl}, 1.8 \mathrm{mM}$ $\mathrm{MgCl}_{2}$ ). PCR cycle consisted of an initial denaturation for $5 \mathrm{~min}$ at $94^{\circ} \mathrm{C}$, followed by 40 cycles each with $1 \mathrm{~min}$ at $94^{\circ} \mathrm{C}, 1 \mathrm{~min}$ at annealing temperature (which differs for different primers), with a final extension of 7 min at $72^{\circ} \mathrm{C}$. The details of primers sequence and the PCR conditions used for amplification are presented in Table 1. Amplified PCR products were resolved in $2 \%$ agarose gel and stained with ethidium bromide.

\section{Results and Discussion}

Although major resistance genes have many disadvantages (Ayliffe et al., 2008), they are still widely used in wheat resistance breeding. In recent years developments in molecular marker techniques and marker identification have facilitated the spread of MAS. This is particularly true in the field of breeding wheat for leaf rust resistance, where PCR-based markers are already available for almost half of the 60 or more designated resistance genes and alleles. Furthermore, all the effective resistance genes designated so far can be traced in segregating progeny populations by means of MAS.

The present work was aimed to identify superior lines for yield and leaf rust resistance with two major leaf rust resistance genes $\operatorname{Lr} 24$ and $L r 28$ in F3 population of DWR $162 \mathrm{X}$ PBW 343. In $F_{1}$ to $F_{3}$ self-generations, selection for the leaf rust resistance genes was performed with SSR and SCAR markers for identifying plants carrying both $L r 24$ and $\operatorname{Lr} 28$, followed by visual selection for better phenotype among the plants carrying both the genes. The homozygous lines were identified and evaluated for yield parameters.

\section{Validation of linked molecular markers}

The presence of expected desired /genes in the parent PBW343 used for transfer of leaf rust resistance was verified by studying DNA polymorphism or lack of it for the linked markers with DWR 162. These markers were consistent with amplification of specific marker fragment size of 320bp with SSR marker Xwmc313, 570bp fragment with SCAR marker S421570 for $\operatorname{Lr} 28$ and $719 \mathrm{bp}$ fragment with the SCAR marker SCS719, $607 \mathrm{bp}$ fragment with the SCAR marker SCS1302 for $\operatorname{Lr} 24$ in PBW 343. This confirmed the presence of both resistance genes in PBW 343 and their absence in DWR 162. This proved the efficiency of SCAR markers SCS719 and SCS421 in marker assisted selection. These markers viz., SCS719 and SCS421 have been effectively utilized for MAS by Revati et al., (2010) and Chhuneja et al., (2005). SCAR marker SCS1302 607 was employed and proved effective for validating the presence of $\mathrm{Lr}_{24}$ in HS424 (Pal et al., 2015). SCAR markers were used for screening of Lr24, Lr 25, and Lr 37 genes (Robert et al., 1999), whereas, STS and RAPD markers were used to validate the presence of $\operatorname{Lr} 9, \operatorname{Lr} 35$, and $\operatorname{Lr} 29$, respectively (Vida et al., 2009) (Table 2 and Fig. 3). 
Fig.1 Screening of $\mathrm{F}_{3}$ lines for the presence of leaf rust resistance genes

Fig.1a Lr28 with SCAR marker SCS 421

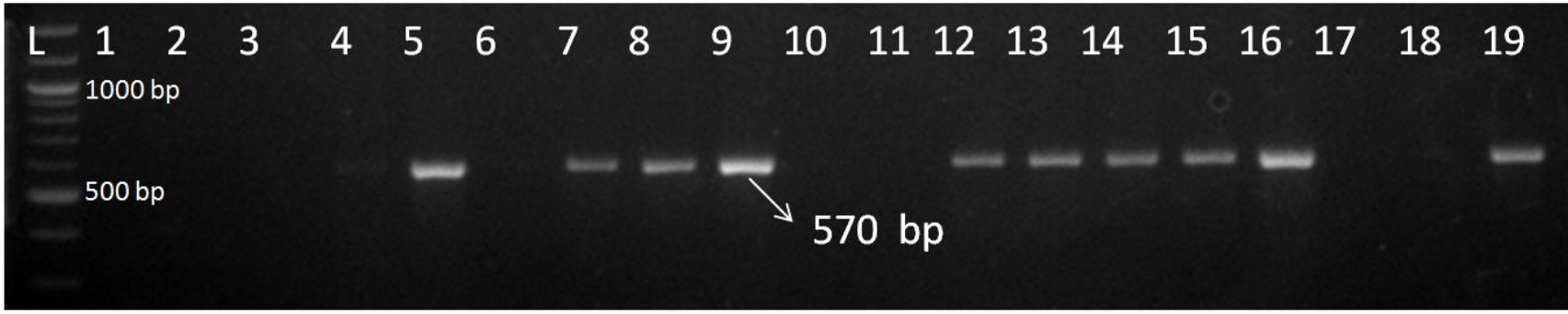

Fig.1b Lr24 with SCAR marker SCS 719

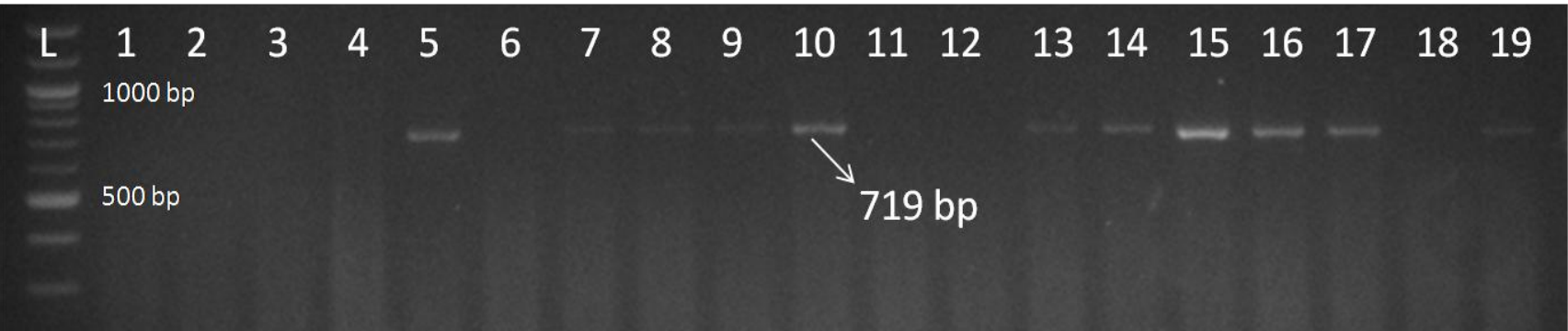

Fig.1c Lr24 with SCAR marker SCS 1302

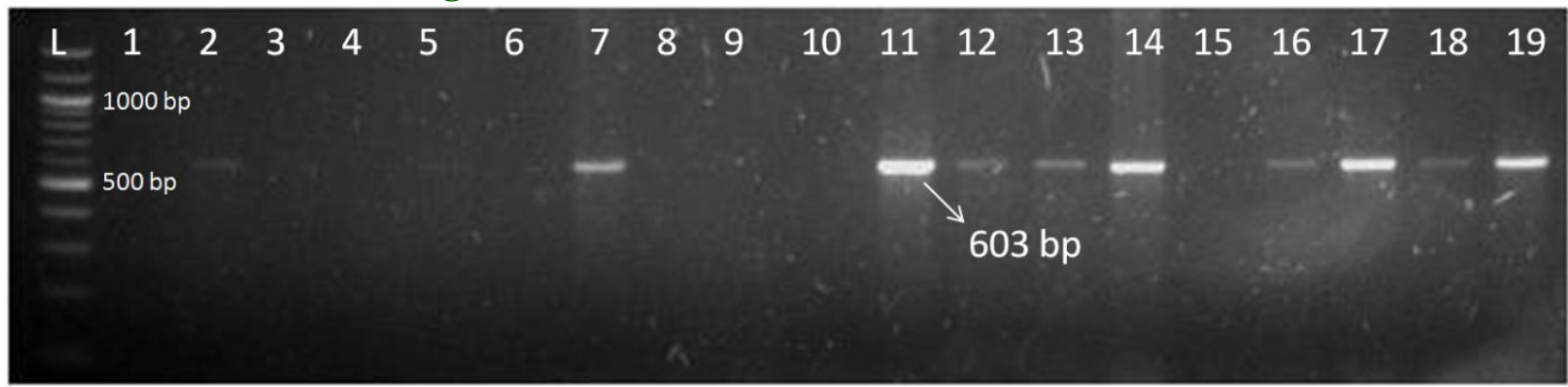

Table.1 Molecular markers for foreground selection of rust resistance Genes used in the study

\begin{tabular}{|l|l|l|c|c|}
$\begin{array}{c}\text { Genes } \\
\text { tagged }\end{array}$ & \multicolumn{1}{|c|}{$\begin{array}{c}\text { Molecular } \\
\text { markers }\end{array}$} & \multicolumn{1}{|c|}{ Primer sequence 5'---3' } & $\begin{array}{c}\text { Amplification } \\
\text { product size. bp) }\end{array}$ & References \\
\hline Lr24 & SCAR:SCS719 & $\begin{array}{l}\text { F: TCG TCC AGA TCA GAA TGT G } \\
\text { R: CTC GTC GAT TAG CAG TGA G }\end{array}$ & 719 & $\begin{array}{c}\text { Prabhu } \text { et } \\
\text { al., }(2004) .\end{array}$ \\
\hline Lr24 & $\begin{array}{l}\text { SCAR:SCS130 } \\
2\end{array}$ & $\begin{array}{l}\text { F: CGC AGG TTC CAA TAC TTT TC } \\
\text { R: CGC AGG TTC TAC CTA ATG CAA }\end{array}$ & 607 & $\begin{array}{c}\text { Gupta } \text { et al., } \\
(2006) .\end{array}$ \\
\hline Lr28 & SCAR:SCS421 & $\begin{array}{l}\text { F: ACA AGG TAA GTC TCC AAC CA } \\
\text { R: AGT CGA CCG AGA TTT TAA CC }\end{array}$ & 570 & $\begin{array}{c}\text { Cherukuri } \text { et } \\
\text { al., }(2005) .\end{array}$ \\
\hline Lr28 & SSR:Xwmc313 & $\begin{array}{l}\text { F: GCA GTC TAA TTA TCT GCT GGC G } \\
\text { R: GGG TCC TTG TCT ACT ATG TCT }\end{array}$ & 320 & $\begin{array}{c}\text { Bipinraj } e t \\
\text { al., }(2011)\end{array}$ \\
\hline
\end{tabular}


Table.2 Superior $\mathrm{F}_{3}$ lines with rust resistance and $L r 24$ and $L r 28$ genes in the cross of DWR 162 X PBW 343

\begin{tabular}{|c|c|c|c|c|c|c|c|c|c|c|}
\hline $\mathbf{F}_{3}$ Line No. & $\begin{array}{l}\text { Days to fifty } \\
\text { percent } \\
\text { flowering }\end{array}$ & $\begin{array}{l}\text { Plant } \\
\text { height } \\
\text { (cm) }\end{array}$ & $\begin{array}{l}\text { Number } \\
\text { of tillers } \\
\text { per plant }\end{array}$ & $\begin{array}{l}\text { Spike } \\
\text { length } \\
\text { (cm) }\end{array}$ & $\begin{array}{l}\text { Number } \\
\text { of } \\
\text { spikelets } \\
\text { per spike }\end{array}$ & $\begin{array}{l}\text { Grain } \\
\text { yield per } \\
\text { plant (g) }\end{array}$ & $\begin{array}{l}\text { Yield per } \\
\text { meter row } \\
\text { (g) }\end{array}$ & $\begin{array}{l}\text { Thousand } \\
\text { grain } \\
\text { weight (g) }\end{array}$ & $\begin{array}{l}\text { Protein } \\
\text { content } \\
(\%)\end{array}$ & $\begin{array}{l}\text { ACI for } \\
\text { leaf rust }\end{array}$ \\
\hline 17 & 67.00 & 79.00 & 11.00 & 9.60 & 19.00 & 14.70 & 73.40 & 38.63 & 13.60 & 8.00 \\
\hline 21 & 75.00 & 78.00 & 14.00 & 9.50 & 20.00 & 16.00 & 80.00 & 36.45 & 13.90 & 2.00 \\
\hline 25 & 70.00 & 81.00 & 16.00 & 10.40 & 22.00 & 17.80 & 89.20 & 43.10 & 12.90 & 0.00 \\
\hline 27 & 71.00 & 80.00 & 9.00 & 10.30 & 20.00 & 18.30 & 91.30 & 33.90 & 13.60 & 2.00 \\
\hline 28 & 66.00 & 77.00 & 11.00 & 9.70 & 20.00 & 17.10 & 85.60 & 36.70 & 12.60 & 12.00 \\
\hline 29 & 77.00 & 83.00 & 13.00 & 10.30 & 19.00 & 20.10 & 100.40 & 37.83 & 12.80 & 8.00 \\
\hline 39 & 71.00 & 78.00 & 10.00 & 9.50 & 19.00 & 16.50 & 82.40 & 34.03 & 13.50 & 4.00 \\
\hline 42 & 76.00 & 74.00 & 15.00 & 10.30 & 20.00 & 16.80 & 83.80 & 37.30 & 12.70 & 2.00 \\
\hline 59 & 74.00 & 73.00 & 13.00 & 9.60 & 20.00 & 25.90 & 129.40 & 35.88 & 12.90 & 4.00 \\
\hline DWR 162 & 66.00 & 86.00 & 20.00 & 10.60 & 19.00 & 23.42 & 96.50 & 38.67 & 14.65 & 65.00 \\
\hline $\begin{array}{l}\text { Improved } \\
\text { PBW } 343 \\
(L r 24+L r 28)\end{array}$ & 84.90 & 66.40 & 11.70 & 9.40 & 18.00 & 12.30 & 56.50 & 31.10 & 12.15 & 5.33 \\
\hline $\mathrm{CD}$ at $5 \%$ & 12.52 & 10.09 & 8.81 & 1.58 & 2.42 & 16.16 & 80.84 & 8.38 & 1.30 & 8.87 \\
\hline S.Em \pm & 4.43 & 3.57 & 3.12 & 0.56 & 0.85 & 5.72 & 28.62 & 2.96 & 0.46 & 3.14 \\
\hline
\end{tabular}




\section{Agronomic evaluation}

A total of 66 lines involving $59 \mathrm{~F}_{3}$ families along with two parents and five checks for yield, quality and rust resistance were evaluated for yield and its component traits. The analysis of variance for all the F3 lines revealed that both the parents and segregating lines differed significantly $(\mathrm{P} \leq 0.01)$ for all the traits under study, showing the existence of abundant genetic variability among the genotypes. Similar findings of high variability in segregating $\mathrm{F}_{3}$ families of wheat have been reported (Yadawad et al., 2015a).

DUS characterization for 26 DUS characters was done identification of individual lines which have recovered most of the characters of DWR 162. Out of fifty nine lines, fifteen $\mathrm{F}_{3}$ lines in both replications recorded similar characters of DWR 162 based on DUS indicating high resemblance with DWR 162. Selection of BC1F2 plants for the recovery of genetic background of recurrent parent DWR162 based on twenty Six DUS characters has been reported (Yadawad et al., 2015b).

\section{Screening in leaf rust screening nursery}

Fifty nine $F_{3}$ segregating progeny rows of rust screening nursery were screened for leaf rust resistance with leaf rust pathotype 77-5, and mixture of races. Out of fifty nine lines, twenty two lines were found to be homozygous resistant, since all the plants within the lines were completely resistant, whereas twenty nine lines found to be segregating with both resistant and susceptible plants within the family. Only eight lines were found to be homozygous susceptible. These twenty two lines which were found to be homozygous resistant were need to be subjected to molecular marker analysis for confirmation of the presence of $L r 24$ and $\operatorname{Lr} 28$ leaf rust resistant genes.
Yadawad et al., (2015b) reported selection of nine homozygous resistant lines from screening of $59 \mathrm{~F}_{3}$ progeny rows for leaf rust incidence in rust screening nursery.

\section{Molecular marker analysis}

Molecular marker analysis was performed on selected twenty two lines which were found to be resistant to identify the homozygous lines carrying both the leaf rust resistant genes.

Out of these, 13 lines showed segregation for Lr24 or $\operatorname{Lr} 28$ genes indicating that these $\mathrm{F}_{2}$ plants were heterozygous for these two genes. Nine lines found to give uniform amplification with all the markers indicating that these lines are homozygous for both the genes.

The alien segment carrying Lr24 does not impose any deleterious effect on yield as several cultivars carrying $\operatorname{Lr} 24$ have been released for cultivation in India has been reported by Singh et al., (2007). Similar report of evaluation of Forty one families of $\mathrm{F}_{3}$ generation for three markers, $\operatorname{Lr} 24, \operatorname{Lr} 28$, and $\operatorname{Lr} 9$ (Charpe et al., 2012) revealed segregation for eight families, several families were either non-segregating for one or more markers and only one family showed no segregation for all the three markers SCS5550, SCS73719 and SCS421570 indicating the homozygosity for all the three genes.

These nine lines superior for agronomic traits with two major leaf rust resistance genes $L r 24$ or $L r 28$ in the desirable background of DWR 162 were advanced to $F_{4}$. These lines can be used as genetic resource in future wheat breeding programs for improving both yield and leaf rust resistance. Further Multi-year / multilocation trials are planned for these lines to evaluate their potential for release for commercial cultivation. 


\section{References}

Ayliffe, M., Singh, R. and Lagudah, E. 2008. Durable resistance to wheat stem rust. Current Opinion in Plant Biology, 11: 187-192.

Bipinraj, A., Honrao, B., Prashar, M., Bhardwa, S., Rao, S. and Tamhankar, S. 2011. Validation and identification of molecular markers linked to the leaf rust resistance gene Lr28 in wheat. J. Applied Genetics, 52: 171-175.

Charpe, A., Koul. S., Gupta, S.K., Singh, A., Pallavi, J.K. and Prabhu, K.V. 2012. Marker assisted gene pyramiding of leaf rust resistance genes $L r$ 9, $L r 24$ and $L r$ 28 in a bread wheat cultivar HD 2329. J. Wheat Research, 4: 20-28.

Chhuneja, P., Vikal, Y., Kaur, S., Singh, R., Juneja, S., Bains, N.S., Berry, O., Sharma, A., Gupta, S. K., Charpe, A., Prabhu, K.V. and Dhaliwal, H.S. 2011. Marker-assisted pyramiding of leaf rust resistance genes Lr24 and Lr28 in wheat. Triticum aestivum. Indian $\mathrm{J}$. Agricultural Sciences, 81(3): 214-218.

Cox, T. S., Raupp, W. J., Gill, B. S. 1994. Leaf rust-resistance genes, Lr41, Lr42 and Lr43 transferred from Triticum tauschii to common wheat. Crop Science, 34: 339-343.

Dellaporta, S.L., Wood, J. and Hicks, J.B. 1983. A plant DNA mini-preparation: version II. Plant Molecular Biology Reporter. 1: 19-21.

Gupta, P.K., Langridge, P., Mir, R.R. 2010. Marker-assisted wheat breeding: present status and future possibilities. Molecular Breeding. 26: 145-161.

Gupta, S., Charpe, A., Koul, S., Prabhu, K.V., Haq, Q.M. 2005. Development and validation of molecular markers linked to an Aegilops umbellulata-derived leaf rust resistance gene, Lr9, for markerassisted selection in bread wheat. Genome, 48: 823-830.
Knott, D.R. 1989. The wheat rusts-breeding for resistance. Monographs on theoretical and applied genetics. Vol 12. Springer, Berlin Heidelberg New York.

Kolmer, J.A., Chen, X. and Jin, Y. 2008a. Diseases which challenge global wheat production the wheat rusts. In: B.F. Carver, editor, Wheat: Science and trade. Wiley-Blackwell, Ames, IA.

Kolmer, J.A., Long, D.L. and Hughes, M.E. 2008b. Physiological specialization of Puccinia triticina on wheat in the United States in 2006. Plant Disease, 92: 1241-1246.

Mebrate, S.A., Oerke, E.C., Dehne, H.W. and Pillen, K. 2008. Mapping of the leaf rust resistance gene Lr38 on wheat chromosome arm 6DL using SSR markers. Euphytica, 162: 457-466.

Nocente, F., Gazza, L., Pasquini, M. 2007. Evaluation of leaf rust resistance genes Lr1, Lr9, Lr24, Lr47 and their introgression into common wheat cultivars by marker-assisted selection. Euphytica, 155: 329-336

Oelke, L.M. and Kolmer, J.A. 2004. Characterization of leaf rust resistance in hard red spring wheat cultivars. Plant Disease, 88: 1127-1133.

Pal, D., Bhardwaj, S.C., Sharma, D., Kumari, S.M., Patial, V. and Pratima, S. 2015. Assessment of genetic diversity and validating rust resistance gene sources using molecular markers in wheat (Triticum aestivum L). Sabrao Journal of Breeding and Genetics, 47: 89-98.

Peterson, R.F., Campbell, A.B. and Hannah, A.E. 1948. A diagram scale for estimating rust severity on leaves and stems of cereals. Canadian J. Research. Section C, 26: 496-500.

Prabhu, K.V., Gupta, S.K., Charpe, A., Koul, S., Cherukuri, D.P. and Dhaliwal, H.S. 2003. Molecular markers detect redundancy and miss-identity in genetic stocks with alien leaf rust resistance 
genes $\operatorname{Lr} 32$ and $\operatorname{Lr} 28$ in bread wheat. J. Plant Biochemistry and Biotechnology, 12: $123-129$

Revathi, P.S., Tomar, M., Vinod, S. and Singh, N.K. 2010. Marker assisted gene pyramiding of leaf rust resistance genes Lr24, Lr28 along with stripe rust resistance gene $\operatorname{Yr} 15$ in wheat. Triticum aestivum L. Indian J. Genetics and plant breeding, 70(40): 349-354.

Robert, O., Abelard, C. and Dedryve, F. 1999. Identification of molecular markers for the detection of the yellow rust resistance gene $\mathrm{Yr} 17$ in wheat. Molecular Breeding, 5: 167-175.

Roelfs, A.P., Singh, R.P. and Saari, E.E. 1992. Rust Diseases of Wheat: Concepts and Methods of Disease Management, Mexico. CIMMYT.

Singh, D., Mohler, V., and Park, R.F. 2012. Discovery, characterization and mapping of wheat leaf rust resistance gene Lr71. Euphytica. 190: 131-136

Singh, R., Datta, D., Priyamvada Singh, S., Tiwari, R. 2004. Marker- assisted selection for leaf rust resistance genes Lr19 and Lr24 in wheat (Triticum aestivum L.). J. Appl. Genet., 45: 399403.

Stakman, E.C., Stewart, D.M. and Loegering, W.Q. 1962. Identification of physiological races of Puccinia graminis var. tritici. Agricultural Research Service E617. USDA, Washington DC.

Stubbs, R.W., Prescott, J.M., Saari, E.E. and Dubin, H.J. 1986. Cereal Disease Methodology Manual, CIMMYT: Mexico.

Vida, G., Gal, M., Uhrin, A., Veisz, O., Syed, N.H. and Flavell, A J. 2009. Molecular markers for the identification of resistance genes and marker-assisted selection in breeding wheat for leaf rust resistance. Euphytica, 170: 67-76.

Yadawad Arati, Hanchinal, R. R., Nadaf, H. L., Desai, S. A., Suma Biradar and Rudra Naik, V. 2015a. Genetic variability and heritability estimates for yield atributes and leaf rust resistance in $\mathrm{F}_{3}$ population of wheat (Triticum aestivum L). The Bioscan. 10(2): 935938.

Yadawad Arati., Hanchinal, R.R., Nadaf, H.L., Desai, S., Suma Biradar and Rudranaik, V. 2015b. Improvement of leaf rust resistance in bread wheat variety DWR162. Triticum aestivum L. through marker assisted selection. Indian J. Genetics and Plant Breeding, 75(2): 256-259.

\section{How to cite this article:}

Arati Yadawad, R.R. Hanchinal, H.L. Nadaf, S.A. Desai, Suma Biradar and Rudranaik, V. 2018. Molecular and Phenotypic Characterization for Leaf Rust Resistance in Bread Wheat (Triticum aestivum L.). Int.J.Curr.Microbiol.App.Sci. 7(10): 1469-1476. doi: https://doi.org/10.20546/ijcmas.2018.710.164 